\title{
IQTISHODUNA
}

Vol. 17 (2), 2021

P-ISSN: 1829-524X, E-ISSN: 26143437

\section{Pengaruh Good Corporate Governance dan Loyalitas terhadap Keputusan Nasabah serta Dampaknya terhadap Kualitas Produk}

\author{
Eka Rahayuningsih \\ Universitas Islam Negeri Sunan Ampel, Jl. Ahmad Yani, Surabaya, Indonesia
}

$凶$ Corresponding Author:

Nama Penulis: Eka Rahayuningsih

E-mail: rahayuningsiheka96@gmail.com

\begin{abstract}
The purpose of this study is to determine the Effect of Good Corporate Governance and Loyalty on Customer Decisions and Their Impacts on Product Quality. The method used is a quantitative type of associative hypothesis. The analysis used is path analysis. The results of this study will prove five hypotheses. The first hypothesis shows the effect of Good Corporate Governance on Decision has a significant effect with $p$ value 0.05 of 0.000. The second hypothesis shows the effect of Loyalty on Decisions has a significant effect with $p$ value 0.05 of 0.000 . The third hypothesis shows the effect of Good Corporate Governance on Product Quality has a significant effect with $p$ value of 0.05 of 0.016. The fourth hypothesis shows the effect of Loyalty on Product Quality has a significant effect with $p$ value of 0.05 of 0.049. The fifth hypothesis shows the influence of Decision on Product Quality has a significant effect with $p$ value 0.05 of 0,000. Path analysis I shows the effect of Good Corporate Governance through Loyalty to product quality directly by 0.044 and indirect effect of 0.293. Path analysis II shows the effect of through Decision on product quality directly at 0.080 and indirect effect at 0.347 .
\end{abstract}

Keywords: Good Corporate Governance (GCG), Loyalty, Decisions, Product Quality

\begin{abstract}
Abstrak: Tujuan dari penelitian ini adalah untuk mengetahui Pengaruh Good Corporate Governance dan Loyalitas Terhadap Keputusan Nasabah Serta Dampaknya Terhadap Kualitas Produk. Metode yang digunakan adalah kuantitatif jenis hipotesis asosiatif. Analisis yang digunakan adalah analisis path. Hasil penelitian ini akan membuktikan lima hipotesis. Hipotesis pertama menunjukkan pengaruh GCG terhadap Keputusan berpengaruh signifikan dengan $p$ value $<0,05$ sebesar 0.000. Hipotesis kedua menunjukkan pengaruh Loyalitas terhadap Keputusan berpengaruh signifikan dengan $p$ value $<0.05$ sebesar 0.000. Hipotesis ketiga menunjukkan pengaruh Good Corporate Governance terhadap Kualitas Produk berpengaruh signifikan dengan $p$ value $<0.05$ sebesar 0.016. Hipotesis keempat menunjukkan pengaruh Loyalitas terhadap Kualitas Produk berpengaruh signifikan dengan $p$ value $<0.05$ sebesar 0.049. Hipotesis kelima menunjukkan pengaruh Keputusan terhadap Kualitas Produk berpengaruh signifikan dengan $p$ value $<0.05$ sebesar 0.000. Analisis jalur I menunjukkan pengaruh Good Corporate Governance melalui Loyalitas terhadap Kualitas produk secara langsung sebesar 0.044 dan pengaruh tidak langsung sebesar 0.293. Analisis jalur II menunjukkan pengaruh melalui Keputusan terhadap Kualitas produk secara langsung sebesar 0.080 dan pengaruh tidak langsung sebesar 0.347 .
\end{abstract}

Kata kunci: Good Corporate Governance (GCG), Loyalitas, Keputusan, Kualitas Produk 
| Submit 10 Oktober 2020 |Diterima 4 Oktober 2021|Terbit 31 Oktober 2021|

\section{Cara mensitasi:}

Rahayuningsih, E. (2020). Pengaruh Good Corporate Governance dan Loyalitas terhadap Keputusan Nasabah serta Dampaknya terhadap Kualitas Produk. Iqtishoduna. Vol. 17 (2): pp 126-140

\section{PENDAHULUAN}

Perkembangan perbankan semakin pesat menimbulkan persaingan bank semakin ketat. Persaingan ini menyebabkan konsep perbankan semakin banyak, sehingga semua bank harus berusaha lebih efektif dan efisien dalam pengelolaan produknya. Jika nasabah ingin mengetahui suatu laporan yang transparansi dan akuntabel dari suatu perbankan, maka bank harus siap. Lembaga perbankan syariah dalam menjalankan bisnisnya tentu memerlukan transparansi, akuntabilitas, responsibilitas, independensi, dan kesetaraan dalam mengelola dana, atau dapat diketahui melalui Good Corporate Governance. Hal tersebut bertujuan agar menarik nasabah untuk memakai produk yang ditawarkan oleh pihak bank.

Transparansi dibangun dari informasi yang bebas dan jelas. Informasi yang tersedia harus memadai, agar informasi tersebut dapat dimengerti dan dipahami. Sistem perekonomian yang berbasis prinsip syariah sangat diinginkan oleh umat Islam Indonesia, bahkan di belahan dunia Islam. Hal tersebut untuk menerapkan segenap aspek kehidupan bisnis dan transaksitransaksi. Perbankan syariah mempunyai beberapa produk dalam proses penyaluran dana kepada masyarakat. Bank itu memperkerjakan seseorang, maka seseorang yang sungguh-sungguh dalam bekerja harus menyampaikan peraturan-peraturan dan akad yang tertera dalam bank tersebut.

Good Corporate Governance sebagai variabel utama selain memiliki kinerja keuangan yang baik perusahaan juga diharapkan memiliki tatakelola yang baik. Dalam penelitian ini indikator mekanisme GCG yang digunakan adalah transparancy, accountability, responsibility, independency dan fairners . Good corporate governance merpakan seperangkat peraturan yang menetapkan hubungan antara pemegang saham, pengurus, pihak kreditur, pemerintah, karyawan serta para pemegang kepentingan internal dan eksternal lainnya sehubungan dengan hak-hak dan kewajiban mereka, atau dengan kata lain sistem yang mengarahkan dan mengendalikan perusahaan (Sunardi, 2019).

Bank harus mempersiapkan diri dengan sebaik-baiknya, agar bank memiliki ketahanan untuk menghadapi daya saing secara sehat dan wajar. Dalam menghadapi daya saing tersebut, industri perbankan mulai berlombalomba untuk memperbaiki diri dengan cara mencapai kinerja yang baik dan optimal. Begitu juga dengan produk yang diterapkan harus sesuai dengan 
Eka Rahayuningsih

perbankan syariah, karena hal itu secara tidak langsung akan berpengaruh positif pada kepercayaan dari masyarakat. Kepercayaan masyarakat terhadap bank akan terwujud, apabila bank memiliki kinerja yang baik dan mampu meningkatkan kinerjanya secara optimal dan berkelanjutan. Produk-produk yang ditawarkan oleh bank meliputi pembiayan mudharabah, bsm tabungan mabrur, bsm investasi cendikia, bsm wadiah, dan sebagainya.

Tabungan mabrur merupakan tabungan yang dikhususkan bagi para nasabah yang ingin menunaikan ibadah haji ke tanah suci. Untuk proses kegiatannya, akad yang digunakan yaitu mudharabah muthalaqah. Pada praktiknya nasabah tidak mendapatkan bagi hasil sesuai dengan akad sebelumnya dan tidak boleh mengambil uang sewaktu-waktu. Namun, dari berbagai macam produk yang ditawarkan oleh pihak bank kepada nasabah, kebanyakan nasabah memutuskan untuk memilih tabungan mabrur di Bank Syariah Mandiri Rungkut Surabaya. Untuk mengetahui pengaruh apa saja yang mendorong nasabah untuk bergabung di bank tersebut dengan menggunakan produk yang ditawarkan oleh bank, peneliti harus mengetahui secara jelas kualitas produk, maupun akad yang diterapkan.

\section{KAJIAN PUSTAKA \\ Teori Good Corporate Governance}

Good Corporate Governance merupakan mekanisme yang dikembangkan dalam rangka meningkatkan kinerja perusahaan dan perilaku pihak manajemen. Terdapat lima prinsip GCG yang dapat dijadikan pedoman bagi suatu korporat atau para pelaku bisnis, yaitu Transparency, Accountability, Responsibility, Indepandency dan Fairness. Good Corporate Governance memberikan suatu struktur yang memfasilitasi penentuan sasaran-sasaran dari suatu perusahaan untuk menentukan teknik monitoring kinerja. Good Corporate Governance (GCG) pada dasarnya merupakan suatu sistem (input, proses, output) dan seperangkat peraturan yang mengatur hubungan antara berbagai pihak yang berkepentingan (stakeholders) terutama dalam arti sempit hubungan antara pemegang saham, dewan komisaris, dan dewan direksi demi tercapainya tujuan perusahaan (Mufidah, 2018)

Di dalam perbankan syari'ah, pelaksanaan GCG pada dasarnya bertumpukan kepada lima pilar utama. Lima pilar tersebut yaitu transparency (keterbukaan, kejujuran), responsibility (pertanggung jawaban), accountability (akuntabilitas), fairness (kewajaran atau keadilan), dan independency (kemandirian atau kebebasan). Asal mula Good Corporate Governace pada bank syariah berawal dari dikeluarkannya Peraturan Bank Indonesia (PBI). Peraturan tersebut yaitu PBI No. 8/4/PBI/2006 tentang Pelaksanaan GCG bagi Bank Umum. Namun sejak tahun 2010, PBI No. 8/4/PBI/2006 sudah tidak berlaku lagi bagi bank syariah. Sebagai gantinya, telah dikeluarkan PBI No. 11/33/PBI/2009 tentang Pelaksanaan GCG bagi Bank Umum Syariah dan Unit Usaha Syariah. Penggantian ini disebabkan, karena GCG yang akan diterapkan pada perbankan syariah harus sesuai dengan prinsip syariah. Pelaksanaan GCG yang memenuhi prinsip syariah yang dimaksudkan dalam PBI ini tercermin dengan adanya pelaksanaan tugas dan tanggung jawab dewan pengawas syariah dalam mengelola kegiatan perbankan syariah. (Dewi, 2020).

Prinsip-prinsip Good Corporate Governance dalam pengelolaan dana 
Pengaruh Good Corporate Governance dan.. disuatu perbankan mencerminkan, bahwa perbankan tersebut telah mengelola dana dengan baik dan transparan. Hal tersebut merupakan modal dasar bagi timbulnya kepercayaan publik, sehingga perbankan yang telah dikenal oleh masyarakat secara luas akan lebih diminati oleh para nasabah dan berdampak positif terhadap peningkatan kualitas produk diperbankan. Lima indikator pencapaian Good Corporate Governance adalah keterbukaan, akuntabilitas, pertanggungjawaban, independensi, dan kewajaran.

Transparansi adalah keterbukaan pemerintah dalam membuat kebijakan-kebijakan, sehingga informasi dapat diketahui oleh masyarakat. Penyelenggaraan tersebut meliputi informasi tentang kebijakan, proses pembuatan serta hasil yang dicapai. Prinsip transparansi akan menciptakan timbal balik antara bank dan nasabah. Melalui informasi yang diberikan oleh bank secara rinci, maka nasabah akan paham. Adanya keterbukaan informasi yang mudah dipahami oleh nasabah, melalui penyediaan informasi yang akurat dan memadai. Transparansi akan mengurangi tingkat ketidakpastian dalam proses pengambilan keputusan seorang nasabah. Selain itu, transparansi dapat menambah peluang nasabah untuk ikut serta menabung di bank dengan produk-produk yang telah diterapkan dengan baik oleh pihak bank.

Akuntabilitas adalah sebuah konsep etika yang dekat dengan administrasi publik pemerintah. Hal tersebut sering digunakan secara sinonim dengan konsep-konsep seperti pertanggungjawaban (responsibility), dipertanyakan (answerability), dapat dipersalahkan (balmeworthiness) dan mempunyai ketidakbebasan (liability). Hal ini dapat menjadi suatu perbincangan di tingkat problembilitas di sektor publik, perusahaan nirlaba, yayasan, dan perusahaan-perusahaan. Pihak bank mempunyai kewajiban untuk melaporkan, menjelaskan dan dapat dipertanyakan bagi setiap nasabah termasuk konsekuensinya. Akuntabilitas merupakan hubungan antara individu, kelompok, atau lembaga dengan nasabah sebagai pertanggungjawaban kepentingan yang wajib diberitahukan, dijelaskan terhadap tiap-tiap tindakan yang dilakukan. Hal tersebut bertujuan agar keputusan yang dibuat dapat disetujui atau ditolak.

Aktivitas perbankan syariah pada dasarnya melekat secara intens sebagai konsekuensi kebersandaran bank syariah pada ajaran Islam. Orientasi bisnis seharusnya membawa kepada bentuk orientasi sosial. Hal tersebut dapat mengetahui konsekuensi pada kuatnya karakter sosial dari perbankan syariah dalam melaksanakan aktivitas-aktivitas sosialnya. Tanggung jawab merupakan sebuah gagasan yang menjadikan suatu lembaga tidak lagi dihadapkan pada tanggung jawab yang berpijak pada single bottom line, yaitu nilai-nilai yang direflesikan dalam kondisi keuangannya saja. Akan tetapi, tanggung jawab harus berpijak pada masalah yang menyangkut sosial dan lingkungan.

Independensi adalah sikap seseorang dalam sudut pandang, pendapat, maupun kesimpulan yang disampaikannya tidak bergantung pada pengaruh dan tekanan dari pihak yang berkepentingan. Independensi merupakan suatu sikap mental yang dimiliki auditor untuk tidak memihak dalam melakukan audit. Nilai audit sangat tergantung pada persepsi publik. Independen dapat 
Eka Rahayuningsih

diukur melalui lama hubungan dengan klien dan tekanan dari klien. Independensi meliputi prestasi dan kepercayaan. Dengan keterbukaan informasi yang baik, nasabah akan lebih bebas memilih produk yang ditawarkan oleh pihak bank. Faktor yang mempengaruhi independensi adalah: (a) Persaingan, (b) Pemberian jasa konsultasi kepada klien atau nasabah, (c) Lamanya hubungan lembaga atau perusahaan dengan klien dan (d) Ukuran keuangan yang dilaporkan.

Setiap nasabah dengan nasabah yang lain harus diperlakukan sama oleh pihak bank. Pihak bank memiliki kekuasaan untuk mengelola dana yang didapat dari nasabah. Pihak bank diperbolehkan mengelola sesuai dengan akad yang telah dilakukan sebelum melakukan transaksi yang dipilih nasabah. Dengan adanya fairness, perbankan dapat membuat pedoman kebijakankebijakan yang melindungi nasabah dari perbuatan yang tidak diinginkan dari konflik kepentingan. Dalam pelaksanaannya, dapat memulihkan layanan atas semua keluhan dari semua masyarakat atau nasabah. Rasa keadilan yang dipersepsikan oleh nasabah kepada pihak bank untuk menimbulkan keinginan memakai produk yang ditawarkan di bank (Prastiwi, 2017).

\section{Teori Loyalitas}

Loyalitas merupakan hubungan antara perilaku seseorang terhadap produk dan perilaku berlangganan. Pemenuhan kebutuhan pelanggan harus disertai dengan memberikan nilai unggul berasal dari pelayanan yang dilakukan oleh bank dan produk berkualitas. Loyalitas layanan merupakan salah satu struktur penting dalam layanan pemasaran berupa pembelian ulang oleh pelanggan dan pelanggan loyal yang melakukan pembelian secara ulang menjadi pertimbangan untuk bisnis lainnya. Hal tersebut dapat berkaitan dengan nasabah melakukan transaksi menabung di bank secara rutin dengan mempertimbangkan sebelumnya (Christian, 2016).

Loyalitas nasabah dapat diketahui melalui pengambilan keputusan yang dilakukan dalam bergabung di bank syariah mandiri. Loyalitas pelanggan dapat tumbuh yang disebabkan oleh beberapa faktor, seperti citra baik yang dimiliki, kualitas pelayanan yang diberikan dan kepuasan terhadap pelanggan. Hal tersebut merupakan peranan penting dalam meningkatkan posisi persaingan. Loyalitas sebagai kondisi pelanggan mempunyai sikap positif terhadap suatu merek, mempunyai komitmen pada merek tersebut, dan bermaksud meneruskan pembeliannya dimasa mendatang. Loyalitas menunjukkan kecenderungan pelanggan untuk menggunakan suatu merek tertentu dengan tingkat konsistensi yang tinggi. Loyalitas selalu berkaitan dengan preferensi pelanggan dan pembelian aktual.

Pelanggan yang loyal memiliki empat karakteristik yaitu: melakukan pembelian secara teratur, melakukan pembelian disemua lini produk atau jasa, merekomendasikan produk lain dan menunjukkan kekebalan dari daya tarik produk sejenis dari pesaing. Enam indikator yang bisa digunakan untuk mengukur loyalitas, yaitu (Hatta, 2017): pembelian ulang, kebiasaan mengonsumsi merek, rasa suka yang besar pada merek, ketetapan pada merek, keyakinan bahwa merek tertentu yang terbaik dan perekomendasian merek kepada orang lain. 


\section{Teori Keputusan}

Keputusan adalah suatu tindakan yang diambil konsumen untuk melakukan pembelian suatu produk yang diawali dengan pengenalan kebutuhan, mendapatkan informasi, menilai dan membandingkan beberapa alternatif pembelian yang ada (Nurul Fatmawati. A, 2017). Keputusan adalah tindakan dari konsumen untuk membeli atau tidak terhadap produk yang mempertimbangkan kualitas dan harga suatu produk. Keputusan pembelian adalah pemilihan dari dua atau lebih alternatif pilihan keputusan pembelian, artinya bahwa seseorang dapat membuat keputusan, harus tersedia beberapa alternatif pilihan. Keputusan untuk membeli atau memakai suatu produk yang ditawarkan dapat mengarah pada proses dalam pengambilan keputusan tersebut itu dilakukan.

Pengambilan keputusan adalah suatu proses pemikiran dalam pemecahan masalah untuk memperoleh hasil yang akan dilaksanakan (Dewi, 2016). Maka dari itu, terkadang ada masalah yang sederhana atau mudah diselaikan dan terkadang ada pula masalah yang sulit untuk diurai cara menyelesaikannya. Semua itu tergantung besar atau kecilnya masalah. Semakin kecil masalahnya semakin mudah cara menyelesaikannya. Sebaliknya semakin besar masalah itu, maka akan semakin sulit cara menyelesaikan atau memutuskannya.

Semakin cepat dan tepat dalam mengambil keputusan dapat dipastikan bahwa nasabah tersebut telah memiliki pengamalan yang banyak. Maka di sinilah distingsi antara nasabah yang berpengalaman dan tidak berpengalaman. Nasabah yang belum berpengalaman akan ada rasa ragu dan khawatiran yang mendalam dalam mengambil keputusan untuk memakai produk di bank tersebut. Rasa ragu dan khawatiran itu wajar, karena yang dipandang tidak hanya kebutuhan untuk dirinya saja, namun mempertimbangkan banyak orang. Karena Ia khawatir keputusannya tidak dapat memuaskan banyak orang.

Dalam mempelajari keputusan konsumen, seorang pemasar harus melihat hal-hal yang berpengaruh terhadap keputusan pembelian atau pemaikaian. Konsumen atau nasabah membuat keputusan melalui (Firmansyah, 2018) : (1) Pengenalan masalah (problem recognition), (2) Pencarian informasi (information search), (3) Evaluasi alternatif (validation of alternativ), (4) Keputusan Pembelian (purchase decision) dan (5) Perilaku pasca pembelian (post purchase behavior).

Kepuasan atau ketidak puasan konsumen terhadap suatu produk akan berpengaruh terhadap pemakaian produk selanjutnya. Jika konsumen puas kemungkinan besar akan menggunakan produk yang ditawarkan oleh bank dengan baik. Ketidakpuasan akan terjadi jika konsumen mengalami pengharapan yang tak terpenuhi. Konsumen atau nasabah yang merasa tidak puas akan menghentikan pemakaian produk yang bersangkutan dan kemungkinan akan menyebarkan berita buruk tersebut ke semua orang. Oleh karena itu, perbankan syariah berusaha memastikan tercapainya kepuasan nasabah pada semua tingkat dalam proses pemakaian produk yang ditawarkan. 
Eka Rahayuningsih

Gaya dan Tipe Pengambilan Keputusan ada empat yaitu gaya direktif, gaya analitik, gaya konseptual, dan gaya behavioral. Gaya Direktif memiliki toleransi yang rendah atas ambiguitas dan mencari rasionalitas. Mereka itu efisien dan logis, tetapi hanya menggunakan informasi minimal dan sedikit alternatif. Manajer tipe ini mengambil keputusan dengan cepat dan orientasi jangka pendek. Gaya Analitik memiliki toleransi yang lebih besar terhadap ambiguitas dan mengarah keinginan menggunakan lebih banyak informasi dan lebih banyak alternatif. Manajer tipe ini sangat cermat dalam mengambil keputusan. Gaya Konseptual menjadi cendrung sangat luas pandangannya. Melakukan pertimbangan yang banyak alternatif orientasinya jangka panjang dan sangat banyak dalam menemukan solusi yang kreatif terhadap masalah yang dihadapi. Gaya Behavioral (tingkah laku) ini dicirikan dengan mengambil keputusan yang bisa bekerja baik dengan yang lain. Manajer tipe ini memperhatikan kinerja rekan kerja dan bawahan serta reseptif terhadap usulan-usulan dari yang lain yang sangat mengandalkan pertemuan untuk berkomunikasi. Manajer gaya ini mencoba menghindarkan konflik dan mengupayakan penerimaan (Kobat, dkk, 2018).

Indikator keputusan antara lain: (1) Pilihan untuk suatu penyedia layanan adalah satu hal yang bijaksana, (2) Melakukan hal yang benar dengan berlangganan pada suatu penyedia layanan dan (3) Secara keseluruhan, layanan yang diberikan adalah memuaskan. Indikator pencapaian yang lainnya dapat dilihat dari: (1) Kebutuhan yang dirasakan, (2) Kegiatan sebelum membeli, (3) Perilaku waktu memakai serta (4) Perilaku pasca pembelian.

\section{Teori Kualitas Produk}

Produk merupakan obyek yang berwujud, maupun yang tidak berwujud yang dapat dibeli orang. Kualitas produk adalah sekumpulan ciri-ciri karakteristik dari barang dan jasa yang mempunyai legitimasi untuk memenuhi kebutuhan (Sellang, 2016). Dimensi dari kualitas produk ini meliputi 8 dimensi yaitu kinerja, keandalan, keistimewaan, kesesuaian dengan spesifikasi, daya tahan, kualitas pelayanan, keindahan, dan persepsi kualitas konsumen. Kinerja (performance) yaitu karakteristik operasi pokok dari produk inti dan dapat didefinisikan sebagai tampilan dari sebuah produk sesungguhnya. Keandalan (reliability) yaitu tingkat keandalan suatu produk atau konsistensi keandalan sebuah produk didalam proses operasionalnya dimata konsumen. Keistimewaan tambahan (features) yaitu karakteristik sekunder atau pelengkap dan dapat didefinisikan sebagai tingkat kelengkapan atribut-atribut yang ada pada sebuah produk. Kesesuaian dengan spesifikasi (conformance to specifications) yaitu sejauh mana karakteristik desain dan operasi memenuhi standar-standar yang telah ditetapkan sebelumnya dan dapat didefinisikan sebagai tingkat dimana semua unit yang diproduksi identik dan memenuhi spesifikasi sasaran yang dijanjikan.

Daya tahan (durability) berkaitan dengan berapa lama produk tersebut dapat terus digunakan dan dapat didefinisikan sebagai suatu ukuran usia operasi produk yang diharapkan dalam kondisi normal dan/atau berat. Serviceability, (service ability) meliputi kecepatan, kompetensi, kenyamanan, 
Pengaruh Good Corporate Governance dan.. mudah direparasi, serta penanganan keluhan yang memuaskan. Aesthethics yaitu keindahan produk terhadap panca indera dan dapat didefinisikan sebagai atribut-atribut yang melekat pada sebuah produk. Customer perceived quality, kualitas yang dipersepsikan (perceived quality) yaitu kualitas yang dirasakan.

Produk menjadi sebuah isu dari sebuah sikap dan kepercayaan kepada penghargaan merek/nama, keputusan dan loyalitas nasabah dalam memakai produk yang ditawarkan oleh pihak bank.

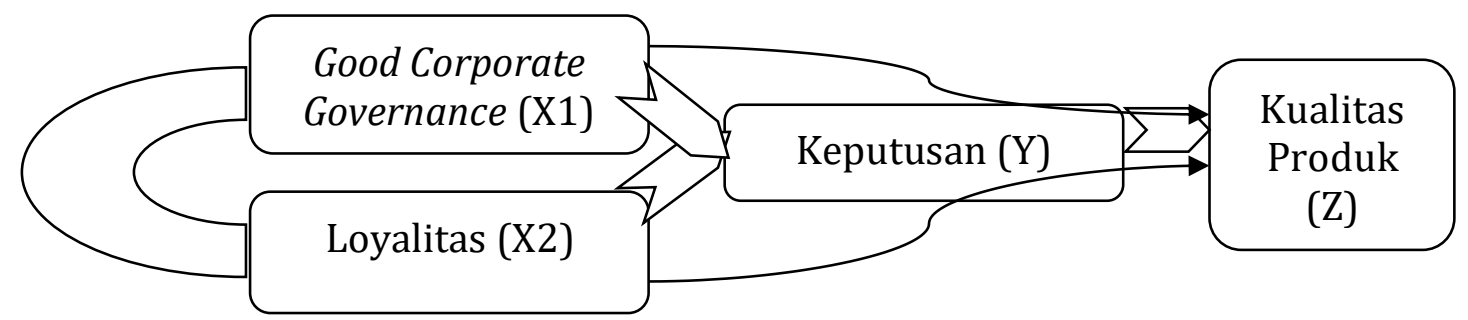

Gambar 1. Kerangka Berpikir Penelitian

\section{METODE PENELITIAN}

Jenis penelitian ini adalah sebab akibat. Penelitian ini menggunakan pendekatan kuantitatif. Variabel dalam penelitian ini adalah Good Corporate Governance (X1), Loyalitas (X2), Keputusan (Y), Kualitas produk (Z). Teknik pengambilan sampel dengan metode simple random sampling. Populasi dalam penelitian ini adalah Nasabah yang bergabung di Bank Syariah Mandiri Rungkut Surabaya. Nasabah merupakan responden yang akan diteliti. Pengumpulan data dalam penelitian ini adalah dengan penyebaran kuesioner, dokumentasi, dan observasi. Responden yang diteliti sebanyak 70 responden yang ada di bank syariah mandiri Rungkut Surabaya mulai dari bulan februari 2020 - maret 2020. Namun pada kenyataannya jumlah angket yang diterima oleh peneliti sebanyak 20 kuesioner, karena terkendala oleh nasabah yang jarang ke bank serta dampak covid-19 yang telah memporak-porandakkan dunia.

\section{Definisi operasional \\ Good Corporate Governance}

Good corporate governance (GCG) merupakan sistem yang mengatur dan mengendalikan perusahaan yang menciptakan nilai tambah untuk semua stakeholder. Ada dua hal yang ditekankan dalam konsep ini, pertama, pentingnya hak pemegang saham untuk memperoleh informasi dengan benar dan tepat pada waktunya dan, kedua, kewajiban perusahaan untuk melakukan pengungkapan (disclosure) secara akurat, tepat waktu, transparan terhadap semua informasi kinerja perusahaan, kepemilikan, dan stakeholder (Thomas S. Kaihatu, 2006). 
Eka Rahayuningsih

Loyalitas

Hubungan antara kualitas layanan dengan loyalitas nasabah bisa dalam bentuk hubungan langsung maupun hubungan tidak langsung dengan diantarai atau dimoderatori oleh kepuasan nasabah (Rachmad Hidayat, 2009).

\section{Keputusan}

Keputusan pembelian mengacu pada perilaku pembelian akhir dari konsumen, baik individual, maupun rumah tangga yang membeli barang dan jasa untuk konsumsi pribadi (Makhdaleva Hanura Tajudin, 2017).

\section{Kualitas produk}

Kualitas produk adalah salah satu faktor yang mempengaruhi keputusan pembelian. Sebuah perusahaan harus memperhatikan kualitas produk yang diciptakannya, karena kualitas produk merupakan suatu faktor penting yang mempengaruhi keputusan para konsumen dalam melakukan pembelian sebuah produk atau jasa (Diah Ernawati, 2019).

\section{HASIL DAN PEMBAHASAN}

Hasil

\section{Hasil Uji Validitas}

Uji validitas meruapakan alat yang digunakan untuk mengukur data itu valid. Kuesioner dinyatakan valid, apabila pernyataan mampu mengungkapkan sesuatu yang akan diukur. Alat yang digunakan untuk pengujian validitas ini menggunakan signifikansi Pearson Correlation. Signifikansi Pearson Correlation memiliki nilai di atas 0,3 (r-kritis) yang berarti instrumen tersebut merupakan contruct yang kuat (Sugiyono, 2016)

Tabel 1. Good Corporate Governance (X1)

\begin{tabular}{cccc}
\hline Pernyataan & Pearson Correlation & r-kritis & Keterangan \\
\hline X1.1 & 0,768 & $>0,3$ & Valid \\
X1.2 & 0,794 & $>0,3$ & Valid \\
X1.3 & 0,670 & $>0,3$ & Valid \\
X1.4 & 0,729 & $>0,3$ & Valid \\
X1.5 & 0,768 & $>0,3$ & Valid \\
X1.6 & 0,794 & $>0,3$ & Valid \\
X1.7 & 0,623 & $>0,3$ & Valid \\
X1.8 & 0,729 & $>0,3$ & Valid \\
X1.9 & 0,623 & $<0,3$ & Valid \\
X1.10 & 0,210 & $>0,3$ & Tidak Valid \\
X1.11 & 0,411 & $>0,3$ & Valid \\
X1.12 & 0,686 & $>0,3$ & Valid \\
X1.13 & 0,623 & $>0,3$ & Valid \\
X1.14 & 0,421 & & Valid \\
\hline
\end{tabular}


Pengaruh Good Corporate Governance dan..

Tabel 2. Variabel Loyalitas (X2)

\begin{tabular}{cccc}
\hline Pernyataan & Pearson Correlation & r-kritis & Keterangan \\
\hline X2.1 & 0,359 & $>0,3$ & Valid \\
X2.2 & 0,581 & $>0,3$ & Valid \\
X2.3 & 0,362 & $>0,3$ & Valid \\
X2.4 & 0,614 & $>0,3$ & Valid \\
X2.5 & 0,510 & $>0,3$ & Valid \\
X2.6 & 0,350 & $>0,3$ & Valid \\
X2.7 & 0,753 & $>0,3$ & Valid \\
X2.8 & 0,304 & $>0,3$ & Valid \\
\hline
\end{tabular}

Tabel 3. Variabel Keputusan (Y)

\begin{tabular}{cccc}
\hline Pernyataan & Pearson Correlation & r-kritis & Keterangan \\
\hline Y.1 & 0,359 & $>0,3$ & Valid \\
Y.2 & 0,581 & $>0,3$ & Valid \\
Y.3 & 0,362 & $>0,3$ & Valid \\
Y.4 & 0,614 & $>0,3$ & Valid \\
Y.5 & 0,510 & $>0,3$ & Valid \\
\hline
\end{tabular}

Tabel 4. Variabel Kualitas Produk (Z)

\begin{tabular}{cccc}
\hline Pernyataan & Pearson Correlation & r-kritis & Keterangan \\
\hline Z.1 & 0,501 & $>0,3$ & Valid \\
Z.2 & 0,535 & $>0,3$ & Valid \\
Z.3 & 0,343 & $>0,3$ & Valid \\
Z.4 & 0,663 & $>0,3$ & Valid \\
Z.5 & 0,471 & $>0,3$ & Valid \\
Z.6 & 0,542 & $>0,3$ & Valid \\
\hline
\end{tabular}

Dari hasil analisi di atas dapat diketahui, bahwa pernyataan dari variabel Good Corporate Governance (X1) terdiri dari 13 item, pernyataan dari variabel Loyalitas (X2) terdiri dari 8 item, pernyataan dari variabel Keputusan (Y) terdiri dari 5 item, dan pernyataan dari variabel Kualitas produk (Z) terdiri dari 6 item dinyatakan valid, karena nilainya kurang dari 0,3. Sebagaimana yang dikemukakan oleh Sugiyono, bahwa "koefisien korelasi lebih dari 0,3 dinyatakan valid".

\section{Uji Reliabilitas}

Uji reliabilitas merupakan alat pengukur yang digunakan untuk mengetahui keterandalan dari pernyataan. Instrumen yang reliabel digunakan bebrapa kali untuk mengukur obyek yang sama, kemudian menghasilkan data yang sama. Uji statistik pada cronbach alpha $(\alpha)$ mempunyai nilai di atas 0,6. Jika nilai yang didapat lebih besar dari 0,6, maka instrumen dapat digunakan untuk pengukuran dalam rangka pengumpulan data (Sugiyono, 2016).

Berdasarkan hasil analisis diketahui bahwa, variabel Good Corporate Governance (X1) memiliki nilai Cronbach's Alpha sebesar 0,895. Variabel 
Eka Rahayuningsih

Loyalitas (X2) memiliki nilai Cronbach's Alpha sebesar 0,723. Variabel Keputusan (Y) memiliki nilai Cronbach's Alpha sebesar 0,610. Variabel Kualitas produk (Z) memiliki nilai Cronbach's Alpha sebesar 0,694. Dari hasil pengolahan dat tersebut diketahui nilai Cronbach's Alpha di atas 0,6. Sehingga pernyataan dari variabel $\mathrm{X} 1, \mathrm{X} 2, \mathrm{Y}$, dan $\mathrm{Z}$ dinyatakan reliabel dan layak dijadikan sebagai bahan penelitian.

\section{Analisis jalur (path analysis)}

Pada analisis jalur merupakan alat yang digunakan untuk menganalisis atau menguji konstruk jalur, apakah teruji secara empiris atau tidak. Analisis selanjutnya dilakukan untuk mencari pengaruh langsung dan tidak langsung dengan menggunakan korelasi dan regresi, sehingga dapat diketahui untuk sampai padavariabel dependen terakhir, harus lewat jalur langsung, atau melalui vaiabel intervening (Sugiyono, 2016). Koefisien Jalur Model I

Tabel 5. Model Summary

\begin{tabular}{llrrrr}
\hline Model & R & R Square & $\begin{array}{c}\text { Adjusted R } \\
\text { Square }\end{array}$ & $\begin{array}{r}\text { Std. Error of } \\
\text { the Estimate }\end{array}$ \\
\hline 1 & $.285^{\mathrm{a}}$ & .581 & .127 & 1.55585 \\
\hline
\end{tabular}

a. Predictors: (Constant), Loyalitas, GCG

Tabel 6. ANOVA ${ }^{\mathrm{b}}$

\begin{tabular}{|c|c|c|c|c|c|c|}
\hline \multicolumn{2}{|c|}{ Model } & \multirow{2}{*}{$\begin{array}{r}\begin{array}{c}\text { Sum of } \\
\text { Squares }\end{array} \\
3.649\end{array}$} & \multirow{2}{*}{$\frac{\mathrm{Df}}{2}$} & \multirow{2}{*}{$\begin{array}{l}\begin{array}{c}\text { Mean } \\
\text { Square }\end{array} \\
1.824\end{array}$} & \multirow{2}{*}{$\frac{\mathrm{F}}{.754}$} & \multirow{2}{*}{$\frac{\text { Sig. }}{.000^{a}}$} \\
\hline 1 & Regression & & & & & \\
\hline & Residual & 41.151 & 17 & 2.421 & & \\
\hline & Total & 44.800 & 19 & & & \\
\hline
\end{tabular}

a. Predictors: (Constant), Loyalitas, GCG

b. Dependent Variable: KEPUTUSAN

Tabel 7. Coefficients ${ }^{a}$

\begin{tabular}{|c|c|c|c|c|c|c|}
\hline \multirow[b]{2}{*}{ Model } & & \multicolumn{2}{|c|}{$\begin{array}{l}\text { Unstandardized } \\
\text { Coefficients }\end{array}$} & \multirow{2}{*}{$\begin{array}{c}\begin{array}{c}\text { Standardized } \\
\text { Coefficients }\end{array} \\
\text { Beta }\end{array}$} & \multirow[b]{2}{*}{$\mathrm{t}$} & \multirow[b]{2}{*}{ Sig. } \\
\hline & & B & Std. Error & & & \\
\hline \multirow[t]{3}{*}{1} & (Constant) & 12.042 & 6.988 & & 1.723 & .000 \\
\hline & GCG & .048 & .057 & .304 & .848 & .000 \\
\hline & $\begin{array}{l}\text { LOYALITA } \\
\mathrm{S}\end{array}$ & .177 & .164 & .360 & 1.078 & .000 \\
\hline
\end{tabular}

a. Dependent Variable: Keputusan 
Pengaruh Good Corporate Governance dan..

Pada tabel coefficients dapat diketahui bahwa nilai signifikansi dari variabel GCG (X1) adalah 0,000 dan variabel Loyalitas (X2) adalah 0,000 lebih kecil dari 0,05. Hasil ini memberikan kesimpulan bahwa regresi model I yaitu variabel X1 dan variabel X2 berpengaruh signifikan terhadap variabel Keputusan (Y). Besarnya nilai $R$ Square yang terdapat pada tabel model Summary adalah sebesar 0,581. Hal ini menunjukkan bahwa sumbangan pengaruh GCG (X1) dan Loyalitas (X2) terhadap Keputusan (Y) sebesar 58,1\%, sementara sisanya 41,9\% merupakan kontribusi dari indikator variabel lain yang tidak dimasukkan dalam penelitian. Sementara itu, untuk nilai (e) dapat dicari dengan rumus e1 $=\sqrt{ }(1-0,581)=0,6473$.

Tabel. 8 Coeffisient Analisis Jalur II

\begin{tabular}{|c|c|c|c|c|c|c|}
\hline \multirow{2}{*}{\multicolumn{2}{|c|}{ Model }} & \multirow{2}{*}{\multicolumn{3}{|c|}{$\begin{array}{lc}\text { lardized } & \text { Standardize } \\
\text { cients } & \begin{array}{c}\mathrm{d} \\
\text { Coefficients }\end{array} \\
\text { Std. Error } & \text { Beta } \\
\end{array}$}} & \multirow{3}{*}{$\begin{array}{l}\mathrm{T} \\
.751\end{array}$} & \multirow{3}{*}{$\begin{array}{l}\text { Sig. } \\
.000\end{array}$} \\
\hline & & & & & & \\
\hline \multirow[t]{4}{*}{1} & (Constant) & 1.337 & 1.781 & & & \\
\hline & GCG & .011 & .014 & .044 & .835 & .016 \\
\hline & LOYALITAS & .060 & .040 & .080 & 1.516 & .049 \\
\hline & KEPUTUSAN & 1.064 & .057 & .964 & 18.661 & .000 \\
\hline
\end{tabular}

a. Dependent Variable: Kualitas Produk

Pada tabel coefficients diketahui bahwa nilai signifikansi dari ketiga variabel yaitu GCG (X1) adalah 0,016, variabel Loyalitas (X2) adalah 0,049, dan variabel Keputusan (Y) adalah 0,000 lebih kecil dari 0,05. Hasil ini memberikan kesimpulan bahwa regresi model II yakni variabel X1, X2, dan Y berpengaruh signifikan terhadap Z. Besarnya nilai $R$ Square yang terdapat pada tabel model summary adalah sebesar 0,961 hal ini menunjukkan bahwa kontribusi GCG (X1), Loyalitas (X2), dan Keputusan (Y) terhadap Keputusan Produk (Z) adalah 96.1\%. Sementara sisanya 3,9\% merupakan kontribusi dari variabel-variabel lain yang tidak diteliti. Sementara untuk nilai e $2=\sqrt{ }(1-$ $0,961)=0,1974$.

\section{Pembahasan}

\section{Pengaruh Good Corporate Governance terhadap keputusan nasabah.}

Analisis pengaruh Good Corporate Governance (X1) terhadap Keputusan (Y) diperoleh nilai signifikansi $\mathrm{X} 1$ sebesar $0,000<0,05$ sehingga dapat disimpulkan bahwa secara langsung terdapat pengaruh signifikan X1 terhadap Y. Good corporate governance (GCG) merupakan prinsip yang mengarahkan dan mengendalikan perusahaan agar mencapai keseimbangan antara kekuatan serta kewenangan perusahaan dalam memberikan pertanggungjawaban kepada pihak-pihak yang berkepentingan, shareholder 
Eka Rahayuningsih

pada khususnya dan stakeholder pada umumnya. Keputusan nasabah dalam memakai Bank Syariah Mandiri merupakan kegiatan yang dipengaruhi oleh Good Corporate Governance. Oleh karena itu, hubungan antara Good Corporate Governance dengan keputusan nasabah merupakan hal yang penting dalam penelitian ini. Good corporate governance (GCG) merupakan sistem yang mengatur dan mengendalikan perusahaan yang menciptakan nilai tambah untuk semua stakeholder. Ada dua hal yang ditekankan dalam konsep ini, pertama, pentingnya hak pemegang saham untuk memperoleh informasi dengan benar dan tepat pada waktunya dan, kedua, kewajiban perusahaan untuk melakukan pengungkapan (disclosure) secara akurat, tepat waktu, transparan terhadap semua informasi kinerja perusahaan, kepemilikan, dan stakeholder (Thomas S. Kaihatu, 2006).

\section{Pengaruh Good Corporate Governance dan loyalitas terhadap kualitas produk.}

Analisis pengaruh Good Corporate Governance (X1) dan loyalitas terhadap Kualitas Produk (Z) diperoleh nilai signifikansi X1 sebesar $0,000<0,05$ sehingga dapat disimpulkan bahwa secara langsung terdapat pengaruh signifikan antara GCG dan loyalitas terhadap kualitas produk. Secara signifikasi di dalam perbankan syari'ah, pelaksanaan GCG pada dasarnya bertumpukan kepada lima pilar utama. Lima pilar tersebut yaitu transparancy (keterbukaan, kejujuran), responsibility (pertanggung jawaban), accountability (akuntabilitas), fairness (kewajaran atau keadilan), dan independency (kemandirian atau kebebasan). Sehingga, dapat diketahui bahwa lima pilar tersebut memberikan pengaruh terhadap kualitas produk di Bank Syariah Mandiri. Hubungan antara kualitas layanan dengan loyalitas nasabah bisa dalam bentuk hubungan langsung maupun hubungan tidak langsung dengan diantarai atau dimoderatori oleh kepuasan nasabah (Rachmad Hidayat, 2009).

\section{Pengaruh Good Corporate Governance dan loyalitas melalui keputusan nasabah terhadap kualitas produk.}

Berdasarkan hasil perhitungan analisis di atas diketahui bahwa nilai pengaruh langsung sebesar 0,044 dan pengaruh tidak langsung sebesar 0,293 yang berarti nilai pengaruh tidak langsung lebih besar dibandingkan dengan nilai pengaruh langsung. Hal ini menunjukkan bahwa secara tidak langsung X1 melalui Y mempunyai penngaruh signifikan terhadap Z. Prinsip-prinsip Good Corporate Governance dalam pengelolaan dana disuatu perbankan mencerminkan, bahwa perbankan tersebut telah mengelola dana dengan baik dan transparan. Modal dasar bagi timbulnya kepercayaan public dapat membantu perbankan telah dikenal oleh masyarakat secara luas akan lebih diminati oleh para nasabah dan berdampak positif terhadap peningkatan kualitas produk diperbankan. Loyalitas pelanggan dapat tumbuh yang disebabkan oleh beberapa faktor, seperti citra baik yang dimiliki, kualitas pelayanan yang diberikan dan kepuasan terhadap pelanggan. Hal tersebut merupakan peranan penting dalam meningkatkan posisi persaingan.

Loyalitas sebagai kondisi pelanggan mempunyai sikap positif terhadap suatu merek, mempunyai komitmen pada merek tersebut, dan bermaksud meneruskan pembeliannya dimasa mendatang. Semakin cepat dan tepat 
Pengaruh Good Corporate Governance dan.. dalam mengambil keputusan dapat dipastikan bahwa nasabah tersebut telah memiliki pengamalan yang banyak. Maka di sinilah distingsi antara nasabah yang berpengalaman dan tidak berpengalaman. Nasabah yang belum berpengalaman akan ada rasa ragu dan khawatiran yang mendalam dalam mengambil keputusan untuk memakai produk di bank tersebut. Rasa ragu dan khawatiran itu wajar, karena yang dipandang tidak hanya kebutuhan untuk dirinya saja, namun mempertimbangkan banyak orang. Karena Ia khawatir keputusannya tidak dapat memuaskan banyak orang. Kualitas produk adalah sekumpulan ciri-ciri karakteristik dari barang dan jasa yang mempunyai legitimasi untuk memenuhi kebutuhan. Pengaruh tersebut dapat juga melalui beberapa indikator lain yang mendukung keputusan pembelian nasabah dalam menggunakan kualitas produk yang telah ditentukan.

\section{SIMPULAN}

Berdasarkan hasil perhitungan dan analisis dari pengaruh pengaruh good corporate governance dan loyalitas terhadap keputusan nasabah serta dampaknya terhadap kualitas produk di bank syariah mandiri Rungkut Surabaya, maka dapat ditarik kesimpulan bahwa variabel good corporate governance dan loyalitas berpengaruh signifikan terhadap keputusan nasabah serta dampaknya terhadap kualitas produk di bank syariah mandiri Rungkut Surabaya. Hal tersebut terbukti dengan adanya pengolahan data melalui statistik.

\section{DAFTAR PUSTAKA}

Christian, M. (2016). Pengaruh Kualitas Layanan terhadap Loyalitas Konsumen Studi Kasus: Belanja Online Bhinneka.Com (Jurnal Siasat Bisnis). Vol. 20 No. 1.

Dewi, I. (2020). Penerapan Good Corporate Governance (GCG) Di Lembaga Perbankan Syariah (Jurnal Al - Tsarwah Program Studi Ekonomi Syariah Pascasarjana IAIN Bone). Vol. 3 No. 2.

Ernawati, D. (2019). Pengaruh Kualitas Produk, Inovasi Produk Dan Promosi Terhadap Keputusan Pembelian Produk Hi Jack Sandals Bandung (Jurnal Wawasan Manajemen). Vol. 7 Nomor 1.

Fatmawati, N. (2017). Kualitas Produk, Citra Merek Dan Persepsi Harga terhadap Proses Keputusan Pembelian Konsumen Sepeda Motor Matic "Honda" (urnal Manajemen Teori dan Terapan Tahun 10). No. 1.

Firmansyah, M. A. (2018). Perilaku Konsumen (Sikap dan Pemasaran) (Grup Penerbitan CV BUDI UTAMA).

Hidayat, R. (2009). Pengaruh Kualitas Layanan, Kualitas Produk dan Nilai Nasabah Terhadap Kepuasan dan Loyalitas Nasabah Bank Mandiri (Jurnal Manajemen Dan Kewirausahaan). VOL.11, NO. 1,.

Hatta, H. (2017). Feature, Nilai, Kepuasan Dan Loyalitas Pelangan (Jurnal Riset Manajemen dan Bisnis). Vol.2, No.1, 45-52.

Kaihatu, T. S. (2006). Good Corporate Governance dan Penerapann ya di Indonesia (Jurnal Manajemen Dan Kewirausahaan). Vol.8, No. 1,.

Kobat, Y. (2018). Pengaruh Gaya Kepemimpinan Demokratis dan Otoriter terhadap Prestasi Kerja Pegawai Negeri Sipil (PNS) Sekretariat Dewan 
Eka Rahayuningsih

Perwakilan Rakyat Aceh (SIMEN (Akuntansi dan Manajemen) STIES). Vol. 9 Issue 2.

Mufidah, N. (2018). Pengaruh Profitabili Tas Terhadap Nilai Perusahaan dengan Pengungkapan Corporate Social Responsibility Dan Good Corporate Gover Nance Sebagai Variabel Mod Erating (El Dinar). Volume 6, No. 1,.

Nastitisari Dewi, R. (2016). Analisis Kemampuan Berpikir Kompleks Siswa Melalui Pembelajaran Berbasis Masalah Berbantuan Mind Mapping (Edusains), Vol. 8 (1), pp: 99-107.

Prastiwi, E. (2017). Pengaruh Inde Pendensi Dewan Pengawas Syariah Dalam Mewujudkan Good Corporate Governance Untuk Meningkatkan Kinerja BMT (Jurnal Ilmiah Ekonomi Islam). VOL. 03 NO. 01.

Sellang, K. (2016). Administrasi Dan Pelayanan Publik Antara Teori dan Aplikasinya (Anggota IKAPI).

Sugiyono. (2016). Metode Penelitian Kuantitatif, Kualitatif, dan R\&D (Alfabeta).

Sunardi, N. (2019). Mekanisme Good Corporate Governance Terhadap Nilai Perusahaan Dengan Leverage Sebagai Variabel Intervening Pada Perusahaan Manufaktur Yang Terdaftar Di Bursa Efek Indonesia Tahun 2012-2018 (J IMF ( Jurnal Ilmiah Manajemen Forkamma)). Vol.2, No. 3.

Tajudin, M. H. (2017). Pengaruh Promosi, Kepercayaan Dan Kesadaran Merek Terhadap Keputusan Nasabah Menggunakan Produk Tabungan Haji (Mabrur) Bank Syariah Mandiri Kcp. Sawangankota Depok (Islamiconomic: Jurnal Ekonomi Islam). Vol.8 No.1. 